\title{
Changes of haematological and biochemical indices with age in rabbits with ad libitum and limited feed intake
}

\author{
Darina Chodová1, Eva Tůmová1, Helena Härtlová2, Alena Fučíková2, \\ Zdeněk Volek ${ }^{3}$, Jana Vlčková ${ }^{1}$ \\ ${ }^{1}$ Czech University of Life Sciences Prague, Faculty of Agrobiology, Food and Natural Resources, \\ Department of Animal Husbandry, \\ ${ }^{2}$ Czech University of Life Sciences Prague, Faculty of Agrobiology, Food and Natural Resources, \\ Department of Veterinary Sciences, Prague, Czech Republic \\ ${ }^{3}$ Institute of Animal Science Prague - Uhř́něves, Prague, Czech Republic
}

Received February 5, 2016

Accepted December 2, 2016

\begin{abstract}
The aim of this study was to examine the effects of a one-week feed restriction of different intensities on haematological and biochemical blood indices at the end of the feed restriction and during the realimentation period in growing rabbits. Hyplus rabbits weaned at 35 days of age $(\mathrm{n}=$ 195) were divided into three groups: rabbits fed ad libitum (AL) and groups with reduced feed of $50 \mathrm{~g}$ (R50) or $65 \mathrm{~g}$ (R65) per rabbit per day from 42 to 49 days of age. At the end of the feed restriction and in the following period, haematological and biochemical blood indices were measured at weekly intervals. The live weight at 70 days of age was lower $(P \leq 0.001)$ in restricted rabbits $(-14.5 \%$ and $-15.5 \%$ for group R50 and R65, respectively, compared to AL). Feed restriction significantly $(P \leq 0.011)$ decreased the number of erythrocytes $(-6.2 \%$ and $-7.4 \%$ for group R50 and R65, respectively, compared to AL) and haemoglobin content $(P \leq 0.008)$. The mean corpuscular volume increased $(P \leq 0.033)$ in restricted rabbits. Interaction of the feeding regime and age $(P \leq 0.007)$ was observed in cholesterol with the highest concentration in R50 at 56 days $(4.41 \mathrm{mmol} / \mathrm{l})$ and the lowest in R65 at 70 days and in AL at 63 days of age $(1.30 \mathrm{mmol} / \mathrm{l})$. The concentration of non-esterified fatty acids $(P \leq 0.003)$ and triacylglycerides $(P \leq 0.048)$ were significantly lower in restricted rabbits. It could be concluded that feed restriction influenced mainly erythrocytes and haemoglobin. The changes in biochemical blood characteristics suggest the restriction did not affect protein metabolism, however, results indicate lipid depletion in restricted rabbits.
\end{abstract}

Hyplus, feed restriction, blood, metabolic characteristic

Limited feed intake is applied in growing rabbits as a prevention of digestive disorders around the post-weaning age (Di Meo et al. 2007). It has been reported to improve feed efficiency (Tůmová et al. 2003; Di Meo et al. 2007; Gidenne et al. 2009, 2012) and to reduce carcass fat deposition (Gondret et al. 2000; Tůmová et al. 2003, 2007).

Blood characteristics in rabbits are used for clinical diagnosis of organic, infectious and several parasitic diseases, detecting stress conditions, and assessing the metabolic condition of animals (Archetti et al. 2008; Çetin et al. 2009). Haematological and biochemical blood indices are influenced by numerous factors including the breed (Martinec et al. 2012), sex (Çetin et al. 2009), age (Jeklova et al. 2009), diurnal and seasonal variation (Çetin et al. 2009), physiological condition (Wells et al. 1999), and nutrition (Addass et al. 2012). Haematological constituents reflect the physiological responsiveness of the animal to the internal and external conditions which include feeding (Etim et al. 2014). There is a lack data of the effect of the feeding regime on haematology in rabbits. For example, Tůmová et al. (2007) stated that most haematology indices in rabbits were not affected by feed restriction, only the lymphocyte counts were increased and neutrophil counts were reduced in the restricted group. In domestic fowl, haemoglobin was reduced when broilers were exposed to stress caused by feed restriction, whereas the number of erythrocytes increased significantly (Maxwell et al. 1990).

Address for correspondence:

Darina Chodová

Department of Animal Husbandry

Czech University of Life Sciences Prague

Kamýcká 129, Prague 6, Suchdol, 165 21, Czech Republic

Phone: +420 224382309

E-mail: chodova@af.czu.cz

http://actavet.vfu.cz/ 
After the end of the feed restriction, when animals are fed ad libitum again, various degrees of compensatory growth can be exhibited in rabbits. These changes in growth during feed restriction and the following realimentation period can be manifested in the proteolytic enzyme function and metabolic processes in the organism represented in changes of biochemical blood indices. There is a lack of information regarding the effect of feed restriction on the biochemical characteristics in rabbits. Van Harten and Cardoso (2010) found that the glucose concentration was not affected by feed restriction in the New Zealand rabbit. Likewise, Sartory et al. (1995) reported that blood glucose concentrations in birds seemed markedly resistant to prolonged feed deprivation. In contrast, Rommers et al. (2004) observed a lower glucose concentration during the period of feed restriction in rabbit does. According to Kersten et al. (1999), fasting decreased adipose tissue lipogenesis and increased the rate of lipolysis. Similarly, van Harten and Cardoso (2010) detected a lower concentration of non-esterified fatty acids (NEFA) and triacylglycerides (TAG) in restricted rabbits. On the other hand, Rommers et al. (2004) observed a similar concentration of NEFA and plasma urea nitrogen in rabbits fed ad libitum and restricted rabbits during the time of feed restriction, however, in the following period, these authors detected higher NEFA as well as TAG concentrations in rabbits fed ad libitum. Data inconsistencies may be affected by the method of feed restriction, its commencement, and duration.

The aim of the current study was to evaluate the effects of a one-week feed restriction with different intensities on haematological and biochemical indices at the end of the feed restriction and during the realimentation period.

\section{Materials and Methods}

The effects of a one-week intensive feed restriction in Hyplus rabbits (PS $19 \times$ PS 59) were studied. The experiment was approved by the Ethics Committee of the Central Commission for Animal Welfare at the Ministry of Agriculture of the Czech Republic. Weaned rabbits with similar live weights at 35 days of age $(n=195)$ were divided into three experimental groups: rabbits fed ad libitum (AL); rabbits with a limited feed intake of $50 \mathrm{~g}$ per animal per day from 42 to 49 days of age (R50); and rabbits with a limited feed intake of $65 \mathrm{~g}$ per animal per day from 42 to 49 days of age (R65). The rabbits were housed in wire net cages with a stocking density of 3 rabbits per cage (floor density of $0.16 \mathrm{~m}^{2}$ per rabbit). Before and following the feed restriction, the rabbits were fed ad libitum. Water was available ad libitum for all groups throughout the whole experiment. Rabbits were fed using a commercial pelleted diet containing $17.1 \%$ crude protein, $20.7 \%$ crude fibre, and $2.8 \%$ ether extract. Environmental conditions were the following: temperature $15-17^{\circ} \mathrm{C}$, relative humidity $55-60 \%$ and lighting regime $12 \mathrm{~L}: 12 \mathrm{D}$.

The live weight was recorded at 35, 42, 49, and 70 days of age. Blood was taken from the jugular vein from eight rabbits per each treatment at the end of the feed restriction at 49 days of age and at weekly intervals. The samples $(n=96)$ for haematological examination were taken into tubes containing dipotassium salt of ethylenediamine tetraacetic acid (K,EDTA). Detection of haematological characteristics was carried out in samples stored at 4 ${ }^{\circ} \mathrm{C}$ within $24 \mathrm{~h}$ after blood collection. The erythrocyte count, leukocyte count, haemoglobin concentration and haematocrit were detected using an automatic haematological analyser Coulter Model ZF (Coulter Electronics Ltd., England). The leukocyte count was detected by staining using the Pappenheim method. The mean cell volume (MCV) was calculated from the erythrocyte count and haematocrit values.

Samples for biochemical evaluation $(\mathrm{n}=96)$ were collected into tubes without an anticoagulant agent. Blood serum was separated by centrifugation of samples at $1,000 \mathrm{~g}$ for $10 \mathrm{~min}$ and then stored at $-70{ }^{\circ} \mathrm{C}$ until analysis. Biochemical indices including concentrations of total protein, urea, glucose, cholesterol, NEFA, and TAG were determined using the commercial set Randox (Randox Laboratories Ltd., Crumlin, UK) and using the spectrophotometer Libra S22 (Biochrom Ltd., UK). The values of blood biochemical indices were determined by counting from the absorbance.

The results were processed by two-way analysis of variance ANOVA (with interaction between group and age) using the general linear model (GLM) procedure of statistical analysis system (SAS Institute Inc. 2003). A $P$ value of $\leq 0.05$ was considered significant for all measurements.

\section{Results}

The live weight of rabbits is shown in Table 1. Live weights of rabbits before feed restriction at 42 days of age did not differ significantly. After the feed restriction at 49 days of age, the live weight decreased significantly $(P \leq 0.001)$ in both restricted groups of 
Table 1. The effect of one-week feed restriction on live weight in broiler rabbits.

\begin{tabular}{|c|c|c|c|c|c|}
\hline Factor & & $\begin{array}{l}\text { Live weight } \\
\text { at } 35 \text { days }(\mathrm{g})\end{array}$ & $\begin{array}{l}\text { Live weight } \\
\text { at } 42 \text { days }(\mathrm{g})\end{array}$ & $\begin{array}{l}\text { Live weight } \\
\text { at } 49 \text { days }(\mathrm{g})\end{array}$ & $\begin{array}{l}\text { Live weight } \\
\text { at } 70 \text { days }(\mathrm{g})\end{array}$ \\
\hline \multirow[t]{3}{*}{ Group } & $\mathrm{AL}$ & 1032 & 1389 & $1865^{\mathrm{a}}$ & $3150^{\mathrm{a}}$ \\
\hline & $\mathrm{R} 50$ & 1029 & 1378 & $1392^{b}$ & $2692^{b}$ \\
\hline & R65 & 1025 & 1355 & $1383^{b}$ & $2662^{b}$ \\
\hline SEM & & 12.00 & 16.02 & 24.75 & 47.53 \\
\hline \multicolumn{6}{|c|}{ Significance } \\
\hline Group & & 0.974 & 0.675 & $<0.001$ & $<0.001$ \\
\hline
\end{tabular}

Different superscripts indicate significant differences $\left({ }^{\mathrm{a}, \mathrm{b}} P \leq 0.05\right)$

$\mathrm{AL}$ - ad libitum; R50 - 50 g of feed per rabbit per day; R65 - $65 \mathrm{~g}$ of feed per rabbit per day

SEM - standard error of the mean

rabbits compared to the control group. At the end of the experiment, both restricted groups had significantly $(P \leq 0.001)$ lower live weights than the group fed ad libitum $(-14.5 \%$ for $\mathrm{R} 50$ and $-15.5 \%$ for R65, compared to AL).

The results of haematological blood indices of restricted rabbits and rabbits fed ad libitum are given in Table 2. No interaction between group and age was detected for the haematological indices. The erythrocyte counts were affected by the feed restriction with significantly $(P \leq 0.011)$ lower values in both restricted groups compared to the rabbits fed ad libitum. The highest differences were detected at 63 and 70 days of age. Erythrocytes in all groups decreased significantly $(P \leq 0.001)$ at 56 days, but in following weeks the

Table 2. The effect of one-week feed restriction on haematological indices in broiler rabbits.

\begin{tabular}{|c|c|c|c|c|c|c|}
\hline Group & Age (days) & Erythrocytes (T/l) & Haemoglobin $(\mathrm{g} / \mathrm{dl})$ & Leukocytes (G/1) & Haematocrit (1/l) & $\operatorname{MCV}(\mathrm{fl})$ \\
\hline \multirow[t]{4}{*}{$\overline{\mathrm{AL}}$} & 49 & $5.80 \pm 0.60$ & $12.51 \pm 1.29$ & $3.23 \pm 1.41$ & $45.38 \pm 4.86$ & $78.13 \pm 2.59$ \\
\hline & 56 & $5.65 \pm 0.47$ & $11.89 \pm 0.60$ & $3.80 \pm 1.98$ & $42.90 \pm 4.14$ & $76.00 \pm 1.69$ \\
\hline & 63 & $6.10 \pm 0.66$ & $12.36 \pm 0.70$ & $4.95 \pm 1.94$ & $44.86 \pm 6.02$ & $73.50 \pm 3.34$ \\
\hline & 70 & $6.25 \pm 0.43$ & $12.65 \pm 0.75$ & $5.53 \pm 2.57$ & $46.03 \pm 1.86$ & $73.88 \pm 3.87$ \\
\hline \multirow[t]{4}{*}{ R50 } & 49 & $6.20 \pm 0.97$ & $13.10 \pm 1.95$ & $2.95 \pm 1.17$ & $47.66 \pm 6.81$ & $77.25 \pm 2.82$ \\
\hline & 56 & $5.02 \pm 0.36$ & $10.81 \pm 0.57$ & $3.58 \pm 0.73$ & $38.76 \pm 3.21$ & $77.25 \pm 2.87$ \\
\hline & 63 & $5.46 \pm 0.22$ & $11.23 \pm 0.65$ & $3.78 \pm 1.40$ & $42.09 \pm 2.00$ & $77.13 \pm 4.49$ \\
\hline & 70 & $5.67 \pm 0.98$ & $12.10 \pm 0.69$ & $5.16 \pm 1.70$ & $41.04 \pm 9.46$ & $74.13 \pm 2.80$ \\
\hline \multirow[t]{4}{*}{ R65 } & 49 & $5.70 \pm 0.30$ & $11.91 \pm 0.67$ & $3.60 \pm 1.52$ & $43.95 \pm 1.69$ & $77.25 \pm 2.19$ \\
\hline & 56 & $5.06 \pm 0.59$ & $11.23 \pm 0.65$ & $4.71 \pm 1.41$ & $41.04 \pm 4.66$ & $79.63 \pm 2.62$ \\
\hline & 63 & $5.54 \pm 0.57$ & $11.51 \pm 0.80$ & $4.70 \pm 1.61$ & $42.45 \pm 3.24$ & $77.00 \pm 3.59$ \\
\hline & 70 & $5.76 \pm 0.63$ & $11.95 \pm 0.66$ & $5.34 \pm 1.13$ & $43.56 \pm 4.81$ & $75.88 \pm 3.23$ \\
\hline SEM & & 0.07 & 0.11 & 0.18 & 0.53 & 0.35 \\
\hline \multicolumn{7}{|c|}{ Significance } \\
\hline \multicolumn{2}{|l|}{ Group } & 0.011 & 0.008 & 0.191 & 0.114 & 0.033 \\
\hline \multicolumn{2}{|l|}{ Age } & $<0.001$ & $<0.001$ & $<0.001$ & 0.013 & 0.002 \\
\hline \multicolumn{2}{|c|}{ Group $\times$ Age } & 0.218 & 0.095 & 0.911 & 0.392 & 0.248 \\
\hline
\end{tabular}

$\mathrm{AL}$ - ad libitum; R50 - $50 \mathrm{~g}$ of feed per rabbit per day; R65 - $65 \mathrm{~g}$ of feed per rabbit per day

MCV - mean cell volume

SEM - standard error of the mean 
erythrocyte counts increased again. The haemoglobin concentrations corresponded with erythrocyte counts and were significantly lower $(P \leq 0.008)$ in both restricted groups. In addition, there was no effect of the feed restriction intensity on this characteristic. The haemoglobin concentration changed significantly with age $(P \leq 0.001)$. The highest haemoglobin concentration was found at 49 days of age and the lowest at 56 days in all groups. Afterwards, the concentration steadily increased. The number of leukocytes $(P \leq 0.001)$ and haematocrit $(P \leq 0.013)$ significantly increased with advancing age, but

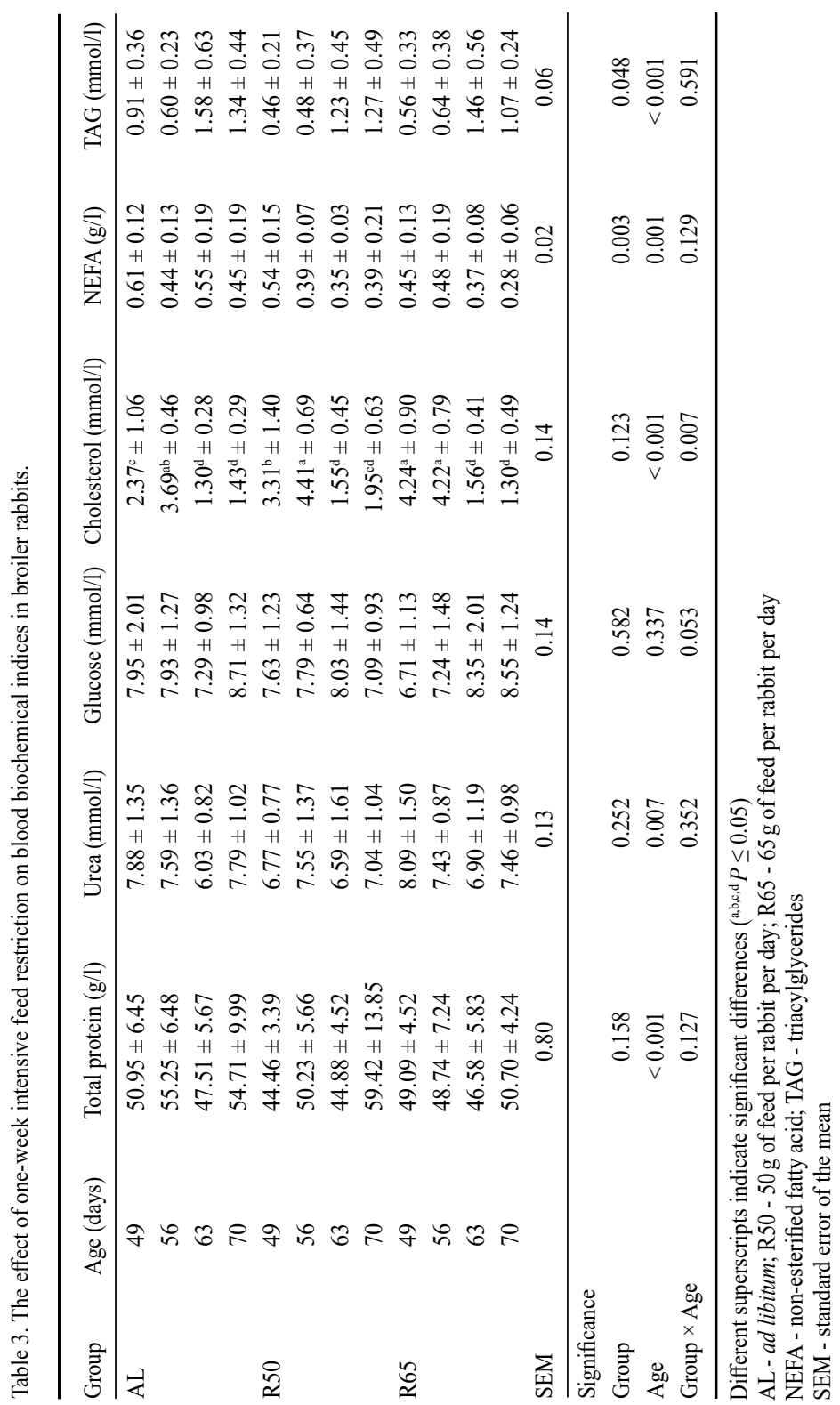

was not affected by feeding regime. The MCV was significantly $\quad(P$ $\leq$ 0.033) affected by feeding regime with higher values in restricted rabbits. However, at the end of restriction at 49 days of age, the restricted rabbits had lower MCV value than the ones fed ad libitum. In the following period, the MCV in all groups decreased $(P \leq 0.002)$ with advancing age.

The biochemical blood characteristics of restricted rabbits and rabbits fed ad libitum are provided in Table 3. The protein metabolism is characterised by concentrations of total protein and urea. Concentrations of both indices were not affected by interaction of the feeding regime and age or by the feeding regime. Total protein concentration was significantly affected by age $(P \leq 0.001)$. The highest total protein values were observed at 56 and at 70 days. Likewise, 
the urea concentration was influenced only by age $(P \leq 0.007)$ with similar trends to those of total protein. Lipid metabolism is represented by the concentration of cholesterol, NEFA and TAG. The significant interaction of the feeding regime and age $(P \leq 0.007)$ was observed only in cholesterol concentration, when the highest values were found in group R50 at 56 days and in group R65 at 49 and 56 days of age. The feeding regime had a significant effect on NEFA $(P \leq 0.003)$ and TAG $(P \leq 0.048)$ concentrations. Lower concentrations were found in both restricted groups without an effect of the feed restriction intensity. The NEFA decreased significantly with age $(P \leq 0.001)$, whereas TAG increased with age $(P \leq 0.001)$.

\section{Discussion}

The results show that immediately after feed restriction, both restricted groups had lower live weights than AL rabbits which was not fully compensated because groups R50 and R65 reached $85.5 \%$ and $84.5 \%$, respectively, of the final live weight of AL rabbits. These results agree with the data of Perrier (1998) who applied feed restriction with an intensity of 50 or $70 \%$ of AL for 3 weeks and detected a lower live weight in the restricted rabbits. Similarly in a study by Larzul et al. (2004) restricted rabbits of 8-18 weeks of age had lower live weights than the control group. Gidenne et al. $(2009,2012)$ also stated that feed restriction significantly decreased the final live weight depending on feed restriction intensity. On the other hand, Tůmová et al. (2007) did not find differences between restricted rabbits and rabbits fed ad libitum with the same period of feed restriction as in the present experiment, only their experiment finished at 84 days. The differing results could be caused by varying times of the beginning or duration of feed restriction. Rabbits with later feed restriction probably do not have sufficient realimentation period to fully compensate their live weights to similar to AL rabbits.

The values of all haematological characteristics studied in the present experiment were within the physiological range described by Hewitt et al. (1989) or by Archetti et al. (2008). Erythrocytes are involved in the transport of oxygen and carbon dioxide. Reduced erythrocyte counts in the restricted rabbits in our experiment did not correspond with the previous study of Tůmová et al. (2007) who did not detect an effect of feed restriction applied from 42 to 56 days of age in rabbits. On the other hand, Silas et al. (2014) observed lower erythrocyte counts in quantitatively restricted chickens compared to chickens fed ad libitum. This variability in erythrocyte counts of restricted rabbits and rabbits fed ad libitum may have been affected by different methods of feed restriction or its experimental timing or a different response of mammals and birds to feed restriction. The erythrocyte count values suggest that the restricted rabbits suffered from erythropoiesis which resulted in a lower erythrocyte concentration.

Haemoglobin is an iron-containing conjugated protein that performs the physiological function of transporting oxygen and carbon dioxide (Gbore and Akele 2010). In our study, haemoglobin changed with the feeding regime and age. On the other hand, Tůmová et al. (2007) did not find an effect of a two-week intensive feed restriction on the haemoglobin content in rabbits, and neither did Silas et al. (2014) in chickens. The decrease of the haemoglobin concentration in our study can be associated with the reduced erythrocyte counts in restricted rabbits.

Higher total leukocyte counts can be used for characterization of malnutrition as indicated in study of Melillo (2007). However, we did not detect an effect of the feeding regime on this haematological indicator in our study. These results were in agreement with Tůmová et al. (2007) who did not observe differences in leukocyte counts between rabbits fed ad libitum and restricted rabbits.

Haematocrit is a toxicity index. No differences of haematocrit values between the groups in our study agree with the results of Tůmová et al. (2007) in rabbits and with Silas 
et al. (2014) in chickens. Non-significantly lower haematocrit in restricted rabbits could have been related to lower growth rates and lower oxygen requirements of these groups as described by Boostani et al. (2010) in restricted chickens.

The MCV is the mean volume of erythrocytes. The one-week intensive feed restriction decreased the MCV at 49 days of age. In the realimentation period, both restricted groups had higher $\mathrm{MCV}$ than the $\mathrm{AL}$ group which is in contrast with the results of Tůmová et al. (2007) in rabbits or of Silas et al. (2014) in chickens who did not observe an effect of the feeding regime.

The biochemical blood characteristics are important for evaluation of the health status of animals and the level of their metabolism. The concentrations of total protein and urea are related to protein metabolism and were within the physiological range described by Archetti et al. (2008) and Özkan et al. (2012). Values were not influenced by the feeding regime which corresponds with Rebollar et al. (2011). The results indicate that the short intensive feed restriction did not affect synthesis and transfer of serum proteins and protein catabolism. It seems that the energy requirement for a growth of rabbits was presumably sufficient even in restricted rabbits because the protein and urea serum concentrations were not affected by the feeding regime which was in agreement with Rajman et al. (2006) and Van Harten and Cardoso (2010). Fat metabolism characteristics such as cholesterol, NEFA, and TAG concentrations were affected by the feeding regime. Cholesterol concentration of restricted rabbits increased at the end of the feed restriction in comparison with the AL rabbits which is not comparable with literature because of lack of data. On the other hand, during the realimentation period, differences between restricted and AL rabbits were not found which is in agreement with the results of El-Speiy et al. (2015) in rabbits and of Rajman et al. (2006), Boostani et al. (2010), and Silas et al. (2014) in chickens. The NEFA and TAG concentrations were lower in restricted rabbits than in AL rabbits after restriction and remained lower during the whole realimentation period. Similarly, van Harten and Cardoso (2010) observed lower NEFA and TAG concentrations at the end of their experiment with rabbits. Lower NEFA and TAG concentrations in the restricted rabbits in our experiment indicates lipid depletion of animals.

Based on our results, it can be concluded that feed restriction may affect erythrocyte counts, MCV, and haemoglobin concentration, and therefore, the transfer of oxygen. However, all measured values were within the physiological range for growing rabbits. No effect of the feeding regime on the protein metabolism was detected. However, cholesterol concentration may vary during restriction and in the realimentation period. The feeding regime significantly decreased NEFA and TAG concentrations which may indicate lipid depletion.

\section{Acknowledgements}

The study was supported by the Ministry of Agriculture of the Czech Republic (Project NAAR No. QJ1510192).

\section{References}

Addass PA, David DI, Edward A, Zira KE, Midak A 2012: Effect of age, sex and management system on some haematological parameters of intensively and semi-intensively kept chicken in Mubi, Adamawa State, Nigeria. Iranian Journal of Applied Animal Science 2: 277-282

Archetti I, Titterelli C, Cerioli M, Brivio R, Grilli G, Lavazza A 2008: Serum chemistry and haematology values in commercial rabbits: Preliminary data from industrial farms in northern Italy. Proceedings of $9^{\text {th }}$ World Rabbit Congress, Verona, Italy: 1147-1152

Boostani A, Ashayerizadeh A, Mahmoodian Fard HR, Kamalzadeh A 2010: Comparison of the effects of several feed restriction periods to control ascites on performance, carcass characteristics and hematological indices of broiler chickens. Braz J Poultry Sci 3: 171-177

Çetin N, Bekyürek T, Çetin T 2009: Effects of sex, pregnancy and season on some haematological and biochemical blood values in Angora rabbits. Scand J Lab Anim Sci 36: 155-162 
Demir E, Sarica S, Sekeroglu A, Ozcan MA, Seker Y 2004: Effects of early and late feed restriction or feed withdrawal on growth performance, ascites and blood constituents of broiler chickens. Acta Agriculturae Scandinavica Section A-Animal Science 3: 152-158

Di Meo C, Bovera F, Marono S, Vella N, Nizza A 2007: Effect of feed restriction on performance and feed digestibility in rabbits. Ital J Anim Sci 6: 765-767

Etim NAN, Williams ME, Akpabio U, Offiong EA 2014: Haematological parameters and factors affecting their values. Agricultural Science 2: 37-47

Gidenne T, Combes S, Feugier A, Jehl N, Arveux P, Boisot P, Briens C, Corrent E, Fortune H, Montessuy S, Verdelhan S 2009: Feed restriction strategy in the growing rabbit. 2. Impact on digestive health, growth and carcass characteristics. Animal 3: 509-515

Gidenne T, Combes S, Fortun-Lamothe L 2012: Feed intake limitation strategies for the growing rabbit: effect on feeding behaviour, welfare, performance, digestive physiology and health: a review. Animal 6: 1407-1419

Gondret F, Lebas F, Bonneau M 2000: Restricted feed intake during fattening reduces intramuscular lipid deposition without modifying muscle fiber characteristics in rabbits. J Nutr 130: 228-233

Hewitt CD, Innes DJ, Savory J, Wills MR 1989: Normal biochemical and haematological values in New Zealand White Rabbits. Clin Chem 35: 1777-1779

Jeklova E, Leva L, Knotigova P, Faldyna M 2009: Age-related changes in selected haematology parameters in rabbits. Res Vet Sci 86: 525-528

Kersten S, Seydoux J, Peters JM, Gonzales FJ, Desvergne B, Wahli W 1999: Peroxisome proliferator-activated receptor $\alpha$ mediates the adaptive response to fasting. J Clin Invest 103: 1489-1498

Króliczewska B, Miśta D, Zawadski W, Wypchlo A, Króliczewski J 2011: Effects of a skullcap root supplement on haematology, serum parameters and antioxidant enzymes in rabbits on a high-cholesterol diet. J Anim Physiol An N 95: 114-124

Martinec M, Härtlová H, Chodová D, Tůmová E, Fučíková A 2012: Selected haematological and biochemical indicators in different breed of rabbits. Acta Vet Brno 81: 371-375

Maxwell MH, Robertson GW, Spence S, McCorquodale CC 1990: Comparison of hematological values in restricted and ad libitum-fed domestic fowls: red blood cell characteristics. Brit Poultry Sci 31: 407-413

Melillo A 2007: Rabbit clinical pathology. J Exot Pet Med 16: 135-145

Özkan C, Kaya A, Akgül Y 2012: Normal values of haematological and some biochemical parameters in serum and urine of New Zealand White rabbits. World Rabbit Sci 20: 253-259

Rajman M, Juráni M, Lamošová D, Máčajová M, Sedlačková M, Košt’ál L, Ježová D, Výboh P 2006: The effects of feed restriction on plasma biochemistry in growing meat type chickens (Gallus gallus). Comp Biochem Physiol A 145: 363-371

Rebollar PG, Pereda N, Schwarz BF, Millán P, Lorenzo PL, Nicodemus N 2011: Effect of feed restriction or feeding high-fibre diet during the rearing period on body composition, serum parameters and productive performance of rabbit does. Anim Feed Sci Tech 163: 67-76

Rommers JM, Boiti C, Brecchia G, Meijerhof R, Noordhuizen JPTM, Decuypere E, Kemp B 2004: Metabolic adaptation and hormonal regulation in young rabbit does during long-term caloric restriction and subsequent compensatory growth. Anim Sci 79: 255-264

Rupic V, Škrlin J, Mužic S, Šerman V, Stipić N, Bačar-Huskić L 1999: Proteins and fats in the serum of rabbits fed different quantities of dried olive cake. Acta Vet Brno 68: 91-98

Sartory DRS, Migliorini RH, Veiga JA, Moura JL, Kettelhut IC, Linder C 1995: Metabolic adaptations induced by long-term fasting in quails. Comp Bioch Physiol A 111: 487-493

SAS 2003: Statistical analysis system, version 9.1.3, 2003. Cary, NC: SAS Institute Inc.

Silas AFA, Ayorinde AO, Daisy E, Mark SO, Bolante OO, Nwakaegho EG 2014: Effect of stocking density and quantitative feed restriction on growth performance, digestibility, haematological characteristics and cost of starting broiler chicks. Journal of Animal Health and Production 2: 60-64

Tůmová E, Skřivanová V, Skřivan M 2003: Effect of restricted feeding time and quantitative restriction in growing rabbits. Arch Geflügelkd 67: 182-190

Tůmová E, Zita L, Skřivanová V, Fučíková A, Skřivan M, Burešová M 2007: Digestibility of nutrients, organ development and blood picture in restricted and ad libitum fed broiler rabbits. Arch Geflügelkd 71: 6-12

Tůmová E, Martinec M, Volek Z, Härtlová H, Chodová D, Bízková Z 2013: A study of growth and some blood parameters in Czech rabbits. World Rabbit Sci 21: 251-256

van Harten S, Cardoso LA 2010: Feed restriction and genetic selection on the expression and activity of metabolism regulatory enzymes in rabbits. Animal 4: 1873-1883

Wells MY, Decobecq CP, Decouvalaere DM, Justice C, Guittin P 1999: Changes in clinical pathology parameters during gestation in the New Zealand white rabbit. Toxicol Pathol 27: 370-379

Yu L, Pragay DA, Chang D, Wicher K 1979: Biochemical parameters of normal rabbit serum. Clin Bioch 12: 83-87 